\title{
Role of Emotional Intelligence on Employee Engagement: A Study among Indian Professionals
}

\author{
Swatee Sarangi ${ }^{1} \&$ Aakanksha Vats $^{1}$ \\ ${ }^{1}$ K. J. Somaiya Institute of Management Studies and Research, India \\ Correspondence: Swatee Sarangi, K. J. Somaiya Institute of Management Studies and Research, India. E-mail: \\ swatee@somaiya.edu
}

Received: March 9, 2015

Accepted: May 20, 2015

Online Published: May 22, 2015

doi:10.5539/ijbm.v10n6p224

URL: http://dx.doi.org/10.5539/ijbm.v10n6p224

\begin{abstract}
Business firms across the globe have always endeavoured to identify and strengthen drivers of employee engagement at the individual, group and organizational level. Drivers at the individual level have been less researched and tested in previous studies. This study attempts to examine the role of emotional intelligence as an individual antecedent of employee engagement. This is hypothesized drawing from literature that emotional intelligence plays an important role in shaping positive workplace feelings, attitudes and behaviour. Responses captured and analyzed from randomly selected sample of 182 professionals working in Indian organizations revealed that emotional intelligence especially mood repair augments high levels of employee engagement manifested through higher vigor, dedication and absorption in employees. These findings have significant implications for both research and practice.
\end{abstract}

Keywords: attention, mood repair, clarity, employee engagement

\section{Introduction}

Employee engagement has been viwed as the keystone of talent management and recipe for organizational success. Kahn (1992) advocated that engagement is instrumental for outcomes at individual (i.e. quality of people's work and their own experiences of doing that work), and organizational-level (i.e. the growth and productivity of organization). Research evidences suggest that engaged employees contribute to increased customer orientation (Chalofsky, 2010), productivity (Saks, 2006) and less turnover (Maslach, Schaufeli \& Leter, 2001; Harter, Schmidt, \& Hayes, 2002; Saks, 2006; Shuck, Reio, \& Rocco, 2011). Engaged employees are assets to the organization as they deliver stellar performances on account of their affective commitment and discretionary efforts (Shuck, 2010). Engaged employees on an average have been found to show less alienation and absenteeism (Wagner \& Harter, 2006) than their peers, saving organizations an average of 86.5 million days per year in lost productivity (The Gallup Organization, 2001). Engaged employees are credited for ensuring financial success and profits (Czarnowsky, 2008; Xanthopoulou, Bakker, \& Schaufeli, 2009). Owing to its manifold benefits and advantages, employee engagement has been attracting attention of practitioners and consulting groups alike.

Research and practice have both unravelled that focusing on drivers of employee engagement can reap rich dividends. Antecedents of engagement were identified at the individual and organizational level (Wollard \& Shuck, 2011). Individual and personality variables are related to burnout (Maslach et al., 2001) and seem to be predicting engagement (Saks, 2006). Previous researches suggest that emotionally intelligent behaviours and abilities are instrumental in shaping socially and organizationally desirable behaviour (Petrides \& Furnham, 2006). Research gap surfaced since few individual drivers especially those having emotional connotations were empirically tested in previous studies.

\subsection{Objective}

The present study was carried out with the objective of examining the role and impact of emotional intelligence as an individual antecedent of employee engagement.

\subsection{Employee Engagement}

Employee Engagement has been differently viewed and defined ever since it was coined by Kahn (1990), who had opined that engagement manifested when individuals expressed themselves physically, cognitively, and 
emotionally through their performances in the job. Its nature (Little \& Little, 2006; Macey \& Schneider, 2008; Shuck, \& Wollard, 2010), measurement (Schaufeli, Bakker, \& Salanova, 2006; for Work Engagement Scale; Harter, Schmidt \& Hayes, 2002; for the Gallup Workplace Audit; Maslach \& Leiter, 2008; for Burnout Inventory), antecedents and consequences (Saks, 2006) and best practices (Macey Schneider, Barbera \& Young, 2009) have shaped the construct of employee engagement.

\subsection{Emotional Connotations of Employee Engagement}

The importance of personal characteristics and attributes are seen as being significantly influencing an individual's behavior at his workplace (Judge, Locke, \& Durham, 1997; Hobfoll 1989; Handa \& Gulati, 2014). These personality traits are generally consistent over a period of time and impact an individual's response to various circumstances at work (Mc Crae, Costa, Ostendorf, Angleitner, Hrebickova, \& Avia, 2000).

Neurotic people have irrational ideas, unable to control impulses and are stressed due to the negative emotions that depart them from adjusting to surrounding including organization (Costa \& McCrae, 1992; Handa \& Gulati, 2014). Positive affect regulates direction, type and speed of cognition (Schwarz \& Bless, 1991; Carver \& White, 1994; Kazan \& Kuhl, 2005). An increase in positive affect, leads to behavioral control and desirable outcomes (Fredrickson, 2005; Bledow, Rosing, \& Frese, 2013).

Emotional connotation of employee engagement concerns the feelings and beliefs of employees (Baumruk, 2004; Shaw, 2005; Richman, 2006; Macey \& Schneider, 2008). Affective commitment emphasizes the emotional connection employees have with their work and is analogous to the emotive qualities of engagement (Macey \& Schneider, 2008; Saks, 2006; Shuck, 2011). Employee's emotional attachment with the organization is viewed as an indispensable factor in shaping commitment and loyalty (Rhoades, Eisenberger, \& Armeli, 2001) which are outcomes of employee engagement. Woodruffe (2006) described engagement as a positive, emotional state which can stimulate employees to willingly engage in behavior directed towards desired organizational outcomes, emphasizing the emotional fulfillment employees experience as a result of being engaged (Shuck \& Wollard, 2010). Even psychological engagement refers to existence of long period of desirable emotions (Albrecht, 2010; Baum \& Mitchell, 2012). Macey and Schneider (2008) make a proposition that an employee who is engaged is within a positive 'state', is attentive, alert, strong, enthusiastic, inspired, proud, determined and active is akin to Alfe's (2010) affective engagement. Emotional make up and positive feelings of employees have an impact on their work and their levels of engagement.

\section{Emotional Intelligence}

Emotional Intelligence coined by Salovey and Mayer (1990) describes abilities like understanding one's own feelings, using emotions to shape judgement and behavior, showing empathy for others' feelings and regulating one's emotions in a way that enhances living (Gibbs, 1995).

Goleman (1995) opined that business success was ensured due to emotional and not cognitive intelligence. It was conceptualized as an ability (Salovey \& Mayer, 1990; Mayer, Salovey \& Caruso, 2002), as a competency (Goleman, 1995), as emotional literacy (Cooper \& Sawaf, 1997), emotional quotient (Cooper, 1997), and personal intelligences (Gardner, 1983), social intelligence (Thorndike, 1920) and interpersonal intelligence (Gardner \& Hatch, 1989).

Emotions influence a range of behaviors that promote both emotional and intellectual growth (Mayer and Salovey, 1997) and are instrumental for self-regulation and positive organizational order (Fineman, 2000). They affect actions, motivations, behavior and practices (Stanley \& Burrows, 2005). Previous research reflects that emotional control, balance and intelligence drive productivity gains, innovations, and accomplishments of individuals, teams and organizations (Cooper, 1997).

Emotional intelligence facilitates flexible planning, improvement in decision-making, creative thinking punctuality and persistence regarding challenging tasks (Salovey \& Mayer, 1990). Individuals with high emotional intelligence are more successful in leading and managing others and developing the right kind of job attitudes amongst other employees (George, 2000). It positively affects job satisfaction, well-being and engagement and, employee perceptions of affective commitment and their turnover intentions (Brunetto, Teo Shacklock, \& Wharton, 2012).

\subsection{Relationship between Emotional Intelligence and Employee Engagement}

Affective engagement has been perceived as the degree to which an individual experiences state of positive affect relating to one's work role (Schaufeli, Salanova et al., 2002; Schaufeli \& Bakker, 2004; May, Gilson, \& Harter, 2004; Truss et al., 2006; Rich, LePine, \& Crawford, 2010; Soane et al., 2012). Affect has been defined as consciously accessible feelings (Fredrickson, 1998). Affect theory distinguishes affective states using two 
dimensions (Warr 1990)-valence (the extent to which an emotion is positive or negative) and activation (the extent to which an emotion is active or passive).

Employee engagement encompasses the positive, activated range of the affect spectrum (Macey \& Schneider, 2008). It is an integral part of employee engagement and plays a pivotal role in motivating individuals for realization of both their individual and organizational goals (Judge \& Illies, 2002; Soane et al., 2012). Appropriate emotions and feelings have strategic value and impact for the organization and the individual (Landen, 2002).

Several studies in the past suggest that emotional intelligence is viewed as an important predictor of organizational outcomes and positive job attitudes including job satisfaction (Grandey, 2000; Abraham, 2000; Carmeli, 2003; Barsade \& Gibson, 2007; Ghoniem, Khouly, Mohsen, \& Ibrahim, 2011; Shooshtarian, Ameli, \& Lari, 2013). Employees having high emotional intelligence have higher levels of job satisfaction due to their ability to identify and regulate their feelings (Sy et al., 2006). This positive relationship has been reported in a nursing study (Guleryuz et al., 2008) and in a study conducted in police services (Brunetto, Teo, Shacklock, \& Wharton, 2012).

Thus, Emotional Intelligence is hypothesized as augmenting higher levels of Employee Engagement.

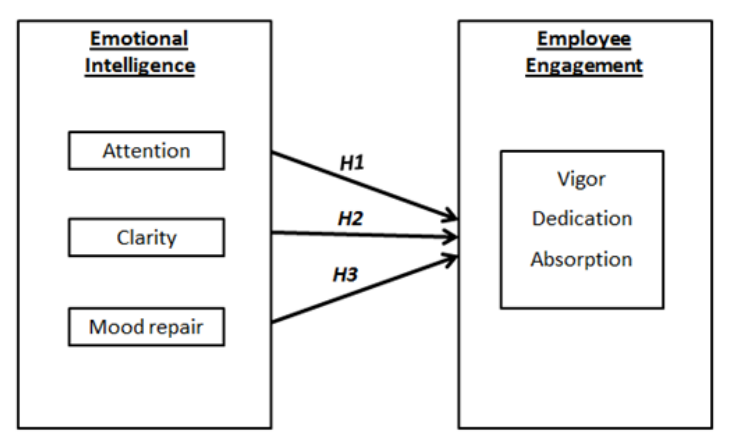

Figure 1. Proposed research model

This research model was used to test the impact of Emotional Intelligence on Employee Engagement.

The dimensions of the construct of Emotional Intelligence have been operationalized as follows:

Attention: It is defined as the degree to which individuals notice and think about their feelings.

Clarity: It refers to the extent to which individuals reported feelings clearly.

Mood Repair: It is the attempt to repair unpleasant moods and maintain positive ones.

The dimensions of Employee Engagement have been operationalized as follows:

Vigor: It is defined by the eagerness and the extent of enthusiasm seen in the employees at the workplaces.

Dedication: It refers to the employees being engrossed and persevering till they achieve their targets, without being perturbed by the external disturbances.

Absorption:It includes complete immersion and involvement in one's work is the definition of absorption.

\subsection{Formulation of Hypotheses}

The following hypotheses are being formulated:

$H 1$ proposes the influence of emotional intelligence on vigor dimension of employee engagement.

H1a. Attention to feelings leads to increased vigor in employees.

H1b. Clarity of feelings is leads to increased vigor in employees.

H1c. Mood Repair leads to increased vigor in employees.

$H 2$ proposes the influence of emotional intelligence on dedication dimension of employee engagement.

H2a. Attention positively impacts dedication of employees.

H2b. Clarity of feelings positively impacts dedication of employees. 
H2c. Mood Repair positively impacts dedication of employees.

$H 3$ proposes the influence of emotional intelligence on absorption dimension of employee engagement.

H3a. Attention leads to increased absorption in employees.

$\boldsymbol{H} 3 \boldsymbol{b}$. Clarity of feelings leads to increased absorption in employees.

H3c. Mood Repair leads to increased absorption in employees.

\subsection{Sampling Design}

The population of this study comprised of young working professionals in the managerial cadre working in Indian organizations. The sample size was 182 respondents of which $34 \%$ of were female and $66 \%$ were male respondents. The respondent's average age was around 25-30 years. They have 5-10 years average organizational tenure.

\section{Instruments and Methods}

Validated and popular instruments were used to measure both the constructs of Emotional Intelligence and Employee Engagement. Meta-Mood Scale (MMS) developed by Salovey, Mayer et al. (1995) comprising of 40 items on a five-point Likert scale comprising of three dimensions of Attention to feelings, Clarity of feelings and Mood Repair was used to measure Emotional intelligence.

The internal consistency of these three scales was evaluated by computing Cronbach's coefficient alpha for each sub scale (Attention: $\alpha=0.86$; Clarity: $\alpha=0.87$; Repair: $\alpha=0.82$ ). Overall scale tested high reliability of 0.85 . For measuring Employee Engagement, scale developed by Schaufeli, Salanova, Gonzalez-Roma and Bakker (2002) comprising of 14 items on a five-point Likert scale comprising of three dimensions of Vigor, Dedication and Absorption was used. The scale reported internal consistency for each sub scale (Vigor $\alpha=0.83$, Dedication $\alpha=$ 0.88 and Absorption $\alpha=0.86$ ). All the scales demonstrated good internal reliability, with each of the alpha coefficients above the minimum desirable value of 0.70 (Nunnally \& Bernstein, 1994). Overall scales tested high reliability of 0.86 . Correlation and Regression analysis were used to analyse the data and test the hypotheses.

\subsection{Results}

Correlations between the variables of the study are presented in Table 1.

Table 1. Inter correlations among the components of EE and EI

\begin{tabular}{|c|c|c|c|c|c|c|c|c|}
\hline Components & Mean & Standard deviation & 1 & 2 & 3 & 4 & 5 & 6 \\
\hline 1. Attention & 3.115 & 0.352 & - & $0.519^{* *}$ & $0.461 * *$ & $0.246^{* *}$ & $0.224^{* *}$ & $0.287 * *$ \\
\hline 2. Repair & 3.270 & 0.408 & & - & $0.415^{* *}$ & $0.331 * *$ & $0.345^{* *}$ & $0.31 * *$ \\
\hline 3. Clarity & 3.178 & 0.380 & & & - & $0.123 * *$ & $0.2^{* *}$ & $0.253 * *$ \\
\hline 4. Dedication & 3.593 & 0.703 & & & & - & $0.697^{* *}$ & $0.6^{* *}$ \\
\hline 5. Vigor & 3.397 & 0.768 & & & & & - & $0.577 * *$ \\
\hline 6. Absorption & 3.488 & 0.610 & & & & & & - \\
\hline
\end{tabular}

Note. ${ }^{* *}$ Correlation is significant at the 0.01 level (2-tailed), $\mathrm{N}=182$.

As seen in Table 1, all dimensions of emotional intelligence are positively correlated with dimensions of employee engagement. The dimension of Mood Repair is showing relatively stronger correlation with Dedication (0.331), Vigor (0.345) and Absorption (0.31) compared to Attention and Clarity. The correlation results provide preliminary support for Hypotheses. 
Table 2. Regression results

\begin{tabular}{|c|c|c|c|c|c|}
\hline Dimensions & Regression Coefficient & Std. error & t - statistic & Sig. & Standard Coefficient \\
\hline \multicolumn{6}{|l|}{ Vigor } \\
\hline Attention & 0.116 & 0.191 & 0.607 & 0.000 & 0.054 \\
\hline Clarity & 0.068 & 0.168 & 0.404 & 0.000 & 0.033 \\
\hline Repair & 0.55 & 0.161 & 3.411 & 0.000 & 0.291 \\
\hline \multicolumn{6}{|l|}{ Intercept } \\
\hline \multicolumn{6}{|c|}{$\mathbf{R}^{2}=0.114$, adj. $\mathbf{R}^{2}=0.099, * * p<0.01$} \\
\hline \multicolumn{6}{|l|}{ Dedication } \\
\hline Attention & 0.286 & 0.175 & 1.637 & 0.000 & 0.145 \\
\hline Clarity & -0.165 & 0.152 & -1.083 & 0.000 & -0.089 \\
\hline Repair & 0.459 & 0.147 & 3.133 & 0.000 & 0.268 \\
\hline \multicolumn{6}{|l|}{ Intercept } \\
\hline \multicolumn{6}{|c|}{$R^{2}=0.111$, adj. $R^{2}=0.095, * * p<0.01$} \\
\hline \multicolumn{6}{|l|}{ Absorption } \\
\hline Attention & 0.250 & 0.153 & 1.635 & 0.000 & 0.143 \\
\hline Clarity & 0.169 & 0.134 & 1.257 & 0.000 & 0.103 \\
\hline Repair & 0.286 & 0.129 & 2.218 & 0.000 & 0.188 \\
\hline \multicolumn{6}{|l|}{ Intercept } \\
\hline \multicolumn{6}{|c|}{$\mathbf{R}^{2}=0.123, \operatorname{adj} . \mathbf{R}^{2}=0.108,{ }^{* *} p<0.01$} \\
\hline
\end{tabular}

Note. $\mathrm{N}=182$.

\subsection{Regression Analysis}

The influence of emotional intelligence on employee engagement was done using multiple regressions. Attention, Clarity and Mood Repair dimensions of Emotional Intelligence were taken as independent predictors for Vigor, Dedication and Absorption dimensions of Employee engagement.

The regression results reveal that R-square value is 0.114 and Emotional Intelligence explains $11 \%$ variance in vigor of employees. As indicated in Table 2, Attention brings about significant changes invigor (Standardized $\beta=0.116 \mathrm{t}=0.607, \mathrm{p}<0.01$ ) providing support for H1a.

It implies that when people attend to their feelings and are conscious of their emotional state, they act from their heart and are likely to be energetic. Further, Clarity (Standardized $\beta=0.068, t=0.404, p<0.01$ ), is significantly related to vigor and provides support for $H 1 b$ but again it is not emerging as a significant predictor. It was hypothesized that individuals who express their feelings clearly should feel positive and energetic and experience vigor. But this could be attributed to clarity of negative feelings and depressions acting as an impediment to vigor. Results of this study revealed that Mood Repair is emerging as a more significant predictor for vigor (Standardized $\beta=0.459, \mathrm{t}=3.411, \mathrm{p}<0.01$ ) compared to Attention and Clarity dimensions and even providing support for $H 1 c$. When employees are able to overcome negativity and maintain positive emotions, they bounce back from negative moods and hence experience positive energy and enthusiasm characterized as vigor.

For the dimension of dedication, R-square value is 0.111 and Emotional Intelligence explains $11 \%$ variance in dedication of employees. The results of the study revealed that Attention is significantly related to Dedication dimension (Standardized $\beta=0.250, \mathrm{t}=1.63, \mathrm{p}<0.01$ ) and provides support for $H 2 a$. This is possible because when employees give attention to their feelings and consider them imperative for their life and happiness, they are focusing more on their affect and likely to persevere for meeting demands of their job. An interesting revelation was that dimension Clarity is negatively related to Dedication (Standardized $\beta=-0.165, \mathrm{t}=-1.083, \mathrm{p}<0.01$ ) and does not provide support for $H 2 b$.

This implies that when employees are clear about their positive and negative feelings both, they are less likely to see meaning in their job, be proud of it and persevere for meeting targets. Mood Repair were found to be significantly associated (Standardized $\beta=0.459, \mathrm{t}=3.133, \mathrm{p}<0.01$ ) and provide support for Hypothesis $2 c$. This implies that when employees are able to repair their negative moods and likely to bounce to positive emotional states they are likely to be dedicated, find meaning and reasons to be proud of their job

Results reveal that for the dimension of absorption, R-square value is 0.123 and Emotional Intelligence explains $12 \%$ variance in absorption of employees With reference to the dimension of Absorption, results revealed that 
Attention was found to be significantly related (Standardized $\beta=0.250, t=1.635, p<0.01$ ) and provides support for $\mathrm{H3a}$. Employees are more absorbed and engrossed in their jobs when they give attention to their feelings. Clarity is significantly related to Absorption (Standardized $\beta=0.169, \mathrm{t}=1.257, \mathrm{p}<0.01$ ) and provide support for $H 3 b$. When employees are clear about their feelings, they are less likely to be disturbed and depressed and hence more likely to be positively absorbed in their jobs. Mood Repair is significantly related to Absorption (Standardized $\beta=0.286, \mathrm{t}=2.218, \mathrm{p}<0.01$ ) and provide support for $H 3 c$. Therefore, when employees have optimistic outlook and can repair moods focusing on pleasant experiences and good thoughts even while feeling bad are the ones who are likely to be absorbed and engaged as they experience happiness while working intensely forgetting trappings of time and pressure.

\section{Discussion and Conclusions}

The study revealed the positive relationship between emotional intelligence and employee engagement. However, the role of emotional intelligence on employee engagement is not as direct as hypothesized on the basis of literature. The study revealed that clarity of feelings is negatively related to dedication dimension of employee engagement. In general, however the study establishes role of emotionally intelligent individuals as capable of showing more vigor, dedication and absorption. These findings are in line with earlier studies where emotional intelligence positively impacted job satisfaction organizational commitment and job attitudes (Carmeli, 2003, Petrides \& Furham, 2006; Li, Ahlstrom \& Ashkanasy, 2010; Brunetto, Teo, Shacklock, \& Wharton, 2012; Shooshtarian, Ameli, Aminilari, 2013; Seyal \& Afzaal, 2013). The results echo that frequently experienced chaotic emotions have been seen as reducing an individual's well-being and generating job burnout (Maslach, Schaufeli, \& Leiter, 2001).

Impetus to experience positive emotions in greater frequency and negative emotions in less frequency (Larsen, Diener, \& Emmons, 1986; Diener, Sandvik, \& Pavot, 1991; Schimmack \& Diener, 1997) as well as a personal experience of joy, contentment, or positive well-being combined with a sense that one's life is worthwhile (Lyubomirsky, 2001; Lyubomirsky, Tkach, \& DiMatteo, 2006) lead to positive job attitudes in previous studies. Emotionally intelligent individuals have been projected assuccessful in communicating their ideas, in interesting and forceful ways (Goleman, 1998; Zeidner et al., 2004), which benefit them and the organization.

The study reveals Mood Repair dimension of emotional intelligence as the most significant predictor of employee engagement. In previous researches, emotionally intelligent individuals have been viewed as those who avoid dysfunctional emotions and use them in adaptive ways to combat feelings of frustration. They display involvement and perseverance in their job as they are emotionally competent (Carmelli, 2000). Mood repair is hierarchically the most difficult and important among the three components of meta-mood experience, followed by emotional clarity and emotional attention. This finding resonates with the premise that emotionally intelligent individuals focus on the resolution of issues faced at work rather than merely reasoning and complaining about the same. They do not criticize the organization for every feeling of frustration (Abraham, 1999), as they are capable of thriving in positive affective states (Carmelli, 2000). Managing distressing moods will enable employees to control impulses, remain hopeful during setbacks, enhance empathy and even develop desirable social skills in organizational settings (Mishra \& Mohapatra, 2009). Wittmer and Martin (2010) opined that emotional exhaustion is a component of burnout where lack of energy is accompanied by feelings of frustration and anxiety. Emotionally exhausted people feel that all their energy is lost and lack vitality (Schaufeli \& Enzmann, 1998). This will surely trigger positive vigor, dedication and absorption in employees.

\section{Recommendations/Managerial Implications}

A contribution of this study has been to throw light on the extent of impact of emotional intelligence on employee engagement. Emotional intelligence should find a place in selection criteria while hiring employees in organizations. It should also be given attention in defining appraisal criteria and considering employees for promotion especially for leadership roles. For enhancing employee engagement organizations can also focus on learning and development interventions to enhance emotional intelligence. Even institutionalizing channels and mechanisms that counter negative emotions can prove beneficial. More specifically, engagement initiatives and programmes can be designed to facilitate mood repair of employees. Emotional intelligence can thrive by promoting and sustaining a healthy work culture and facilitating high levels of employee engagement. Even counseling can help to counter negative emotions and channelize positive emotions that will trigger vigor, dedication and absorption of employees.

\section{Limitations and Directions for Future Research}

Future studies may capture sectoral differences. Even searching and ascertaining the role of mediating and moderating variables in this relationship can be explored in future research endeavors. The same research 
question can be tested through multiple sources like employees and their supervisors.

\section{References}

Abraham, R. (1999). Emotional intelligence in organizations: A conceptualization. Genetic, Social, and General Psychology Monographs, 125(2), 209-224.

Abraham, R. (2000). The role of job control as a moderator of emotional dissonance and emotional intelligence-outcome relationships. The Journal of Psychology, 134(2), 169-184. http://dx.doi.org/10.1080/00223980009600860

Albrecht, S. L. (2010). Handbook of employee engagement: Perspectives, issues, research and practice. Edward Elgar Publishing.

Soane, E., Truss, C., Alfes, K., Shantz, A., Rees, C., \& Gatenby, M. (2012). Development and application of a new measure of employee engagement: The ISA Engagement Scale. Human Resource Development International, 15(5), 529-547. http://dx.doi.org/10.1080/13678868.2012.726542

Barsade, S. G., \& Gibson, D. E. (2007). Why does affect matter in organizations? The Academy of Management Perspectives, 21(1), 36-59.

Baumruk, R. (2004). The missing link: The role of employee engagement in business success. Workspan, 47(11), 48-52.

Bledow, R., Rosing, K., \& Frese, M. (2013). A dynamic perspective on affect and creativity. Academy of Management Journal, 56(2), 432-450.

Brunetto, Y., Teo, S. T., Shacklock, K., \& Farr-Wharton, R. (2012). Emotional intelligence, job satisfaction, well - being and engagement: Explaining organisational commitment and turnover intentions in policing. Human Resource Management Journal, 22(4), 428-441. http://dx.doi.org/10.1111/j.1748-8583.2012.00198.x

Carmeli, A. (2003). The relationship between emotional intelligence and work attitudes, behavior and outcomes: An examination among senior managers. Journal of Managerial Psychology, 18(8), 788-813. http://dx.doi.org/10.1108/02683940310511881

Carver, C. S., \& White, T. L. (1994). Behavioral inhibition, behavioral activation, and affective responses to impending reward and punishment: The BIS/BAS scales. Journal of Personality and Social Psychology, $67(2), 319$.

Chalofsky, N. E. (2010). Meaningful workplaces: Reframing how and where we work. John Wiley \& Sons.

Cooper, R. K. (1997). Applying emotional intelligence in the workplace. Training and Development, 51(12), 31-38.

Cooper, R. K., \& Sawaf, A. (1997). Emotional Intelligence in Business. Orion.

Costa Jr, P. T., \& McCrae, R. R. (1992). Four ways five factors are basic. Personality and Individual Differences, 13(6), 653-665. http://dx.doi.org/10.1016/0191-8869(92)90236-I

Crawford, E. R., LePine, J. A., \& Rich, B. L. (2010). Linking job demands and resources to employee engagement and burnout: A theoretical extension and meta-analytic test. Journal of Applied Psychology, 95(5), 834. http://dx.doi.org/10.1037/a0019364

Czarnowsky, M. (2008). Learning's role in employee engagement. American Society for Training and Development: Author.

Diener, E., Sandvik, E., \& Pavot, W. (1991). Happiness is the frequency, not the intensity, of positive versus negative affect. Subjective Well-Being: An Interdisciplinary Perspective, 21, 119-139.

El Khouly, S., Ghoniem, A., Ghadami, M., \& Ibrahim, M. (2011). Impact of emotional intelligence and gender on job satisfaction among Egyptian government sector employees. Current Research Journal of Social Sciences, 3(1), 22-27.

Fineman S. (2000). 1 Emotional arena revisited. Emotion in organizations.

Franche, R. L., Baril, R., Shaw, W., Nicholas, M., \& Loisel, P. (2005). Workplace-based return-to-work interventions: optimizing the role of stakeholders in implementation and research. Journal of Occupational Rehabilitation, 15(4), 525-542. http://dx.doi.org/10.1007/s10926-005-8032-1

Fredrickson, B. L., \& Losada, M. F. (2005). Positive affect and the complex dynamics of human flourishing. 
American Psychologist, 60(7), 678. http://dx.doi.org/10.1037/0003-066X.60.7.678

Gardner, H., \& Hatch, T. (1989). Educational implications of the theory of multiple intelligences. Educational Researcher, 18(8), 4-10. http://dx.doi.org/10.3102/0013189X018008004

Gardener, H. (1983). Frames of mind: The theory of multiple intelligences. New York: Basic.

George, J. M. (2000). Emotions and leadership: The role of emotional intelligence. Human Relations, 53(8), 1027-1055. http://dx.doi.org/10.1177/0018726700538001

Gibbs, N. (1995). The EQ factor. Time Magazine, 146(14), 68-75.

Goleman, D. (1998). Working with emotional intelligence. Random House LLC.

Goleman, D. P. (1995). Emotional intelligence: Why it can matter more than IQ for character, health and lifelong achievement.

Grandey, A. A. (2000). Emotional regulation in the workplace: A new way to conceptualize emotional labor. Journal of Occupational Health Psychology, 5(1), 95. http://dx.doi.org/10.1037/1076-8998.5.1.95

Güleryüz, G., Güney, S., Aydın, E. M., \& Aşan, Ö. (2008). The mediating effect of job satisfaction between emotional intelligence and organisational commitment of nurses: A questionnaire survey. International Journal of Nursing Studies, 45(11), 1625-1635. http://dx.doi.org/10.1016/j.ijnurstu.2008.02.004

Handa, M., \& Gulati, A. (2014). Employee Engagement. Journal of Management Research, 14(1), 57-67. http://dx.doi.org/10.15171/ijhpm.2015.12

Harter, J. K., Schmidt, F. L., \& Hayes, T. L. (2002). Business-unit-level relationship between employee satisfaction, employee engagement, and business outcomes: A meta-analysis. Journal of Applied Psychology, 87(2), 268. http://dx.doi.org/10.1037/0021-9010.87.2.268

Hobfoll, S. E. (1989). Conservation of resources: A new attempt at conceptualizing stress. American Psychologist, 44(3), 513. http://dx.doi.org/10.1037/0003-066X.44.3.513

Judge, T. A., Bono, J. E., Ilies, R., \& Gerhardt, M. W. (2002). Personality and leadership: A qualitative and $\begin{array}{llllll}\text { quantitative review. Journal of Applied Psychology, } & 87(4), & 765 .\end{array}$ http://dx.doi.org/10.1037/0021-9010.87.4.765

Judge, T. A., Locke, E. A., \& Durham, C. C. (1997). The dispositional causes of job satisfaction: A core evaluations approach. Research in Organizational Behavior, 19, 151-188. http://dx.doi.org/10.1037/0021-9010.83.1.17

Kazan, M., \& Kuhl, J. (2005). Intention memory and achievement motivation: Volitional facilitation and inhibition as a function of affective contents of need-related stimuli. Journal of Personality and Social Psychology, 89(3), 426-448.

Khurram, M., Sarmad, M., Abbas, M., \& Amanullah, K. M. (2011). Impact of emotional intelligence on employee's performance in telecom sector of Pakistan. African Journal of Business Management, 5(4), 1225-1231.

Landen, M. (2002). Emotion management: Dabbling in mystery-white witchcraft or black art? Human Resource Development International, 5(4), 507-521. http://dx.doi.org/10.1080/13678860110057665

Larsen, R. J., Diener, E., \& Emmons, R. A. (1986). Affect intensity and reactions to daily life events. Journal of Personality and Social Psychology, 51(4), 803. http://dx.doi.org/10.1037/0022-3514.51.4.803

Law, K. S., Wong, C. S., Huang, G. H., \& Li, X. (2008). The effects of emotional intelligence on job performance and life satisfaction for the research and development scientist in China. Asia Pacific Journal of Management, 25(1), 51-59. http://dx.doi.org/10.1007/s10490-007-9062-3

Li, Y., Ahlstrom, D., \& Ashkanasy, N. M. (2010). A multilevel model of affect and organizational commitment. Asia Pacific Journal of Management, 27(2), 193-213. http://dx.doi.org/10.1007/s10490-010-9193-9

Little, B., \& Little, P. (2006). Employee engagement: Conceptual issues. Journal of Organizational Culture, Communications and Conflict, 10(1), 111-120.

Lyubomirsky, S., Tkach, C., \& DiMatteo, M. R. (2006). What are the differences between happiness and self-esteem? Social Indicators Research, 78(3), 363-404. http://dx.doi.org/10.1007/s11205-005-0213-y

Macey, W. H., \& Schneider, B. (2008). The meaning of employee engagement. Industrial and Organizational Psychology, 1(1), 3-30. http://dx.doi.org/10.1111/j.1754-9434.2007.0002.x 
Maslach, C., \& Leiter, M. P. (2008). Early predictors of job burnout and engagement. Journal of Applied Psychology, 93(3), 498. http://dx.doi.org/10.1037/0021-9010.93.3.498

Maslach, C., Schaufeli, W. B., \& Leiter, M. P. (2001). Job burnout. Annual Review of Psychology, 52(1), 397-422. http://dx.doi.org/10.1146/annurev.psych.52.1.397

May, D. R., Gilson, R. L., \& Harter, L. M. (2004). The psychological conditions of meaningfulness, safety and availability and the engagement of the human spirit at work. Journal of Occupational and Organizational Psychology, 77(1), 11-37. http://dx.doi.org/10.1348/096317904322915892

Mayer, J. D., \& Salovey, P. (1997). What is emotional intelligence? In P. Salovey and D. Sluyter (Eds.), Emotional development and emotional intelligence: Implications for educators (pp. 3-31). New York: Basic Books.

McCrae, R. R., Costa Jr, P. T., Ostendorf, F., Angleitner, A., Hřebíčková, M., Avia, M. D., \& Smith, P. B. (2000). Nature over nurture: Temperament, personality, and life span development. Journal of Personality and Social Psychology, 78(1), 173. http://dx.doi.org/10.1037/0022-3514.78.1.173

Mishra, P. S., \& Mohapatra, A. K. (2009). Emotional Intelligence in the Occupational Settings: A Literature-Based Analysis of the Concept and its Measurement. South Asian Journal of Management, 16(3).

Nunnally, J. C., \& Bernstein, I. H. (1994). Psychological theory.

Petrides, K. V., \& Furnham, A. (2006). The Role of Trait Emotional Intelligence in a Gender-Specific Model of Organizational Variables1. Journal of Applied Social Psychology, 36(2), 552-569. http://dx.doi.org/10.1111/j.0021-9029.2006.00019.x

Rhoades, L., Eisenberger, R., \& Armeli, S. (2001). Affective commitment to the organization: The contribution of perceived organizational support. Journal of Applied Psychology, 86(5), 825. http://dx.doi.org/10.1037/0021-9010.86.5.825

Richman, A. (2006). Everyone wants an engaged workforce how can you create it. Workspan, 49(1), 36-39.

Saks, A. M. (2006). Antecedents and consequences of employee engagement. Journal of Managerial Psychology, 21(7), 600-619. http://dx.doi.org/10.1108/02683940610690169

Salovey, P., \& Mayer, J. D. (1990). Emotional intelligence. Imagination, Cognition and Personality, 9(3), 185-211. http://dx.doi.org/10.2190/DUGG-P24E-52WK-6CDG

Schaufeli, W. B., \& Bakker, A. B. (2004). Job demands, job resources, and their relationship with burnout and engagement: A multi-sample study. Journal of Organizational Behavior, 25(3), 293-315. http://dx.doi.org/10.1002/job.248

Schaufeli, W. B., Bakker, A. B., \& Salanova, M. (2006). The measurement of work engagement with a short questionnaire a cross-national study. Educational and Psychological Measurement, 66(4), 701-716. http://dx.doi.org/0.1177/001316440528247

Schaufeli, W. B., Salanova, M., González-Romá, V., \& Bakker, A. B. (2002). The measurement of engagement and burnout: A two sample confirmatory factor analytic approach. Journal of Happiness Studies, 3(1), 71-92. http://dx.doi.org/10.1023/A:1015630930326

Schaufeli, W., \& Enzmann, D. (1998). The burnout companion to study and practice: A critical analysis. CRC press.

Schimmack, U., \& Diener, E. (1997). Affect intensity: Separating intensity and frequency in repeatedly measured affect. Journal of Personality and Social Psychology, 73(6), 1313. http://dx.doi.org/10.1037/0022-3514.73.6.1313

Schneider, B., Macey, W. H., Lee, W. C., \& Young, S. A. (2009). Organizational service climate drivers of the American Customer Satisfaction Index (ACSI) and financial and market performance. Journal of Service Research, 12(1), 3-14. http://dx.doi.org/10.1177/1094670509336743

Schwarz, N., Bless, H., Strack, F., Klumpp, G., Rittenauer-Schatka, H., \& Simons, A. (1991). Ease of retrieval as information: Another look at the availability heuristic. Journal of Personality and Social Psychology, 61(2), 195. http://dx.doi.org/10.1037/0022-3514.61.2.195

Seyal, A. H., \& Afzaal, T. (2013). An investigation of relationship among emotional intelligence, organizational commitment and job satisfaction: Evidence from academics in Brunei Darussalam. International Business Research, 6(3), 217. http://dx.doi.org/10.5539/ibr.v6n3p217 
Shooshtarian, Z., Ameli, F., \& AminiLari, M. (2013). The Effect of Labor's Emotional Intelligence on Their Job Satisfaction, Job Performance and Commitment. Iranian Journal of Management Studies, 6(6), 27-43.

Shuck, B. (2011). Four emerging perspectives of employee engagement: An integrative literature review. Human Resource Development Review. http://dx.doi.org/10.1177/1534484311410840

Shuck, B., \& Wollard, K. (2010). Employee engagement and HRD: A seminal review of the foundations. Human Resource Development Review, 9(1), 89-110. http://dx.doi.org/10.1177/1534484309353560

Shuck, B., \& Reio, T. G. (2011). The employee engagement landscape and HRD: How do we link theory and scholarship to current practice? Advances in Developing Human Resources, http://dx.doi.org/1523422311431153

Shuck, B., Reio Jr, T. G., \& Rocco, T. S. (2011). Employee engagement: An examination of antecedent and outcome variables. Human Resource Development International, 14(4), 427-445. http://dx.doi.org/10.1080/13678868.2011.601587

Soane, E., Truss, C., Alfes, K., Shantz, A., Rees, C., \& Gatenby, M. (2012). Development and application of a new measure of employee engagement: The ISA engagement scale. Human Resource Development International, 15(5), 529-547.

Fredrickson, B. L. (1998). Cultivated emotions: Parental socialization of positive emotions and self-conscious emotions. Psychological Inquiry, 9(4), 279-281. http://dx.doi.org/10.1080/13678868.2012.726542

Stanley, R. O., \& Burrows, G. D. (2005). The role of stress in mental illness: The practice. Handbook of Stress Medicine and Health, 87-100.

Sy, T., Tram, S., \& O'hara, L. A. (2006). Relation of employee and manager emotional intelligence to job satisfaction and performance. Journal of Vocational Behavior, 68(3), 461-473. http://dx.doi.org/10.1016/j.jvb.2005.10.003

The Gallup Organization. (2001). What your disaffected workers cost. Gallup Management Journal. Retrieved from http://gmj.gallup.com/content/439/What- Your-Disaffected-Workers-Cost.aspx

Truss, C., Soane, E., Edwards, C., Wisdom, K., Croll, A., \& Burnett, J. (2006). Working Life: Employee Attitudes and Engagement 2006. London, CIPD.

Wagner, R., \& Harter, J. K. (2006). 12: The elements of great managing (Vol. 978, No. 1-59992). Gallup Press.

Warr, P. (1990). The measurement of well - being and other aspects of mental health. Journal of Occupational Psychology, 63(3), 193-210. http://dx.doi.org/10.1111/j.2044-8325.1990.tb00521.x

Warr, P. B. (1990). Decision latitude, job demands, and employee well-being. Work and Stress, 4(4), 285-294. http://dx.doi.org/10.1080/02678379008256991

Wittmer, J. L., \& Martin, J. E. (2010). Emotional exhaustion among employees without social or client contact: The key role of nonstandard work schedules. Journal of Business and Psychology, 25(4), 607-623.

Wollard, K. K., \& Shuck, B. (2011). Antecedents to Employee Engagement: A Structured Review of the Literature. Advances in Developing Human Resources, 13(4), 429-446.

Wong, C. S., \& Law, K. S. (2002). The effects of leader and follower emotional intelligence on performance and attitude: An explanatory study. The Leadership Quarterly, 13(3), 243-274. http://dx.doi.org/10.1016/S1048-9843(02)00099-1

Woodruffe, C. (2006). The crucial importance of employee engagement. Human Resource Management International Digest, 14(1), 3-5. http://dx.doi.org/10.1108/09670730610643891

Xanthopoulou, D., Bakker, A. B., Demerouti, E., \& Schaufeli, W. B. (2009). Work engagement and financial returns: A diary study on the role of job and personal resources. Journal of Occupational and Organizational Psychology, 82(1), 183-200. http://dx.doi.org/10.1348/096317908X285633

Zeidner, M., Matthews, G., \& Roberts, R. D. (2004). Emotional intelligence in the workplace: A critical review. Applied Psychology, 53(3), 371-399.

\section{Copyrights}

Copyright for this article is retained by the author(s), with first publication rights granted to the journal.

This is an open-access article distributed under the terms and conditions of the Creative Commons Attribution license (http://creativecommons.org/licenses/by/3.0/). 